\title{
Direct method for construction of prosthetic bite opening and positioning stents for head and neck tumor radiotherapy
}

\author{
Luiz Cesar da Costa Filho ${ }^{a}$, Wilson José de Almeida Jr. ${ }^{b}$, Marina Currac ${ }^{c}$, Rosemarie Franzkowiak Stahlschmidt ${ }^{\mathrm{d}}$, \\ Daniela Vargas Barletta ${ }^{d}$, Luis Carlos da Fontoura Frasca ${ }^{\mathrm{e}}$
}

\begin{abstract}
INTRODUCTION: Radiotherapy for head and neck tumors causes a series of adverse effects. Some effects are temporary, such as oral mucositis and taste disorders, and others are permanent, such as xerostomia and increased risk for dental caries and osteoradionecrosis. One way to diminish radiotherapy's adverse effects is to decrease the radiation dose on healthy tissues outside the tumor area through more precise radiotherapy techniques, such as intensity-modulated radiation therapy (IMRT), which depends on positioners and stabilizers to the anatomic structures.

CASE REPORT: This paper presents direct construction technique examples of mouth openers and positioning stents for tongue and mandible, which allow distance from the radiation field for healthy organs as well the precise stabilization required for the IMRT technique.

CONCLUSION: The clinical cases shown in the present paper also illustrate that the intra-oral devices for stabilization of the dental arches and tongue are effective in reducing unnecessary radiation on healthy organs.
\end{abstract}

Keywords: radiotherapy; dental prostheses; cancer of head and neck.

\section{Método direto de construção para abridores de boca e posicionadores protéticos para radioterapia de cabeça e pescoço}

\section{RESUMO}

INTRODUÇÃO: A radioterapia de tumores na região de cabeça e pescoço causa uma série de efeitos adversos. Alguns desses efeitos são temporários, como mucosites e diugesia; e outros permanentes, como xerostomia, risco a ostorradionecrose e risco a cáries. Uma das formas de diminuir os efeitos colaterais da radioterapia é diminuir a dose de radiação de estruturas saudáveis fora da área do tumor através de técnicas radioterápicas mais precisas como a radioterapia de intensidade modulada (IMRT) a qual depende de posicionadores e estabilizadores das estruturas anatômicas.

RELATO DO CASO: O presente artigo demonstra exemplos de confecção direta de abridores de boca e posicionadores de língua e mandíbula que permitem o afastamento das estruturas saudáveis bem como a estabilização precisa necessária à técnica do IMRT.

CONCLUSÃO: Os casos clínicos apresentados no presente artigo também ilustram que os dispositivos intraorais para estabilização das arcadas dentárias e da língua são eficientes em diminuir a dose de radiação desnecessária a estruturas saudáveis.

Palavras-chave: radioterapia; prótese dentária; câncer de cabeça e pescoço.

\author{
a Head of the Dental Team, Hospital Moinhos de \\ Vento, Porto Alegre, RS, Brasil \\ ${ }^{b}$ Head of the Radiotherapy Service, Hospital \\ Moinhos de Vento, Porto Alegre, RS, Brasil \\ c Adjunct Professor, Universidade de Caxias do Sul, \\ Caxias do Sul, RS, Brasil \\ d Radiation Doctor, Hospital Moinhos de Vento \\ Porto Alegre, RS, Brasil

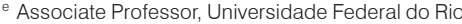 \\ Grande do Sul, Porto Alegre, RS, Brasil
}

Correspondence: Luiz Cesar da Costa Filho periodontia@rocketmail.com

Received: October 2, 2017 Accepted: March 15, 2018

Conflict of Interests: The authors state that there re no financial and personal conflicts of interest that could have inappropriately influenced their work.

Copyright: @ 2017 Costa Filho et al.; licensee EDIPUCRS

This work is licensed under a Creative Commons Attribution 4.0 International License. 


\section{INTRODUCTION}

Radiotherapy is an essential ally to the treatment of head and neck tumors, although it generates a series of adverse effects that must to be known by dentists and radiation oncologist with the purpose to prevent and/or minimize such effects during and after the radiation treatment. Some side effects are transitory, such as oral mucositis, candidiasis, taste disorders, and dysphagia $[1,2]$; others are permanent, such as xerostomia $[3,4]$ and a consequent risk of dental caries (especially root caries [5]) and osteoradionecrosis $[6,7]$.

The evolution of machines and techniques are decreasing radiation doses [8] as well as toxicity to healthy tissues. Radiotherapy has evolved from 2D planning (conventional radiotherapy) to $3 \mathrm{D}$ planning, and has now evolved to intensity-modulated radiation therapy (IMRT) and imageguided radiation therapy (IGRT). These last two techniques allow less toxicity to the healthy tissues surrounding the irradiated tumor [9-12]. The risk of dental caries and osteoradionecrosis can be managed through a rigorous dental treatment before, during, and after the radiation treatment. But permanent xerostomia is extremely difficult to handle and also decreases the patients' quality of life $[13,14]$ after the radiation treatment, because it affects swallowing and phonation and increases the risk of dental caries $[2,15]$.

Although the evolution of machines and planning techniques have diminished the adverse effects, much can still be done to protect healthy organs during head and neck radiation therapy, especially for the salivary glands [16].
Some strategies for salivary gland protection during radiotherapy are: radiation prosthesis $[17,18]$, bethanechol use [19,20], pilocarpine use [21], low level laser therapy [22], and submandibular gland surgical transfer [23].

The purpose of this paper is to show the direct method of fabrication of bite opening and positioning stent for dental arches and the tongue for radiotherapy of head and neck tumors, as well to discuss the advantages of these devices.

\section{CASES DESCRIPTIONS}

\section{CASE \#1. Patient with nasal floor carcinoma (Figures 1 and 2).}

This case describes the classical technique of direct manufacturing of a dental device with mouth opening and positioning fixation of the tongue.

Once obtained, upper and lower casts stones the occlusal stents with auto polymerized acrylic (Figures 1A and 1B).

In the sequence, an artificial tongue is made with alginate (Figure 1C) in order to pre-fabricate a lingual plate for tongue stabilization with auto polymerized acrylic (Figures 1D and 1E).

After a previous clinical adjustment of the occlusal stents, silicone adhesive is applied in the inner portion of the occlusal stents (Figure 1F). In the sequence, fluid addition silicone impression material is applied and tacked into the proper position in the mouth (Figures $\mathbf{1 G}$ and $\mathbf{1 H}$ ). The purpose of applying silicone is to promote more retention and comfort to the patient (Figure 1I).
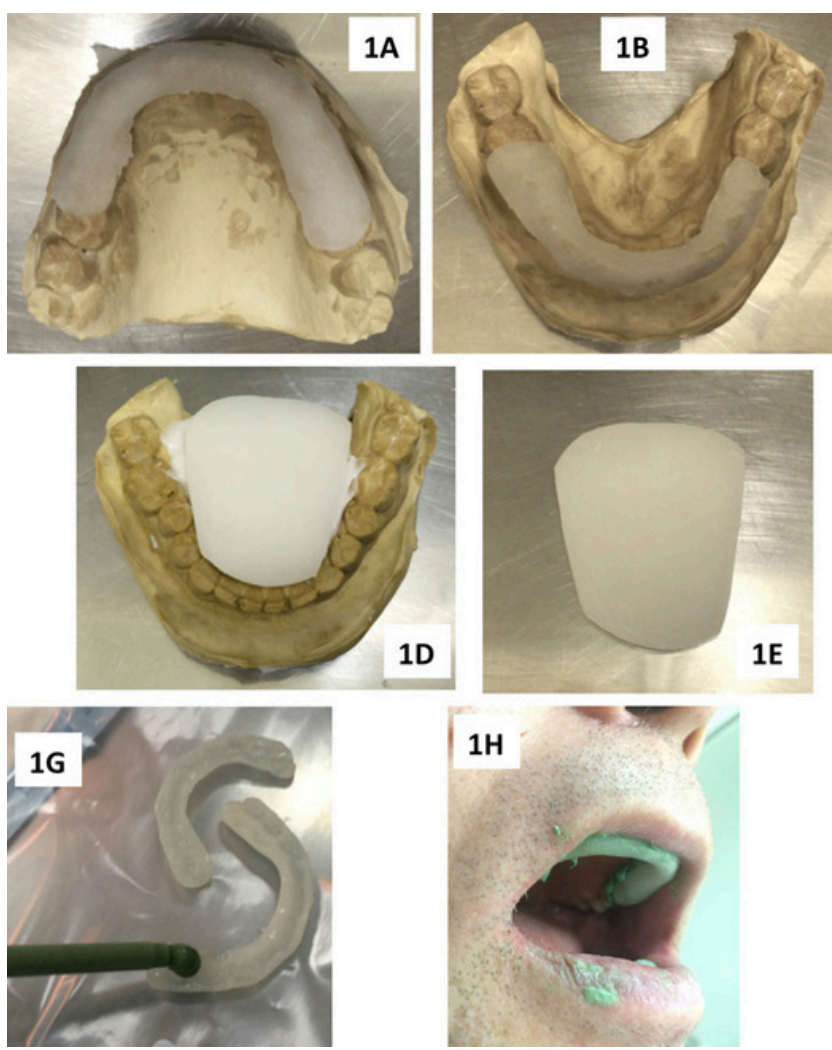
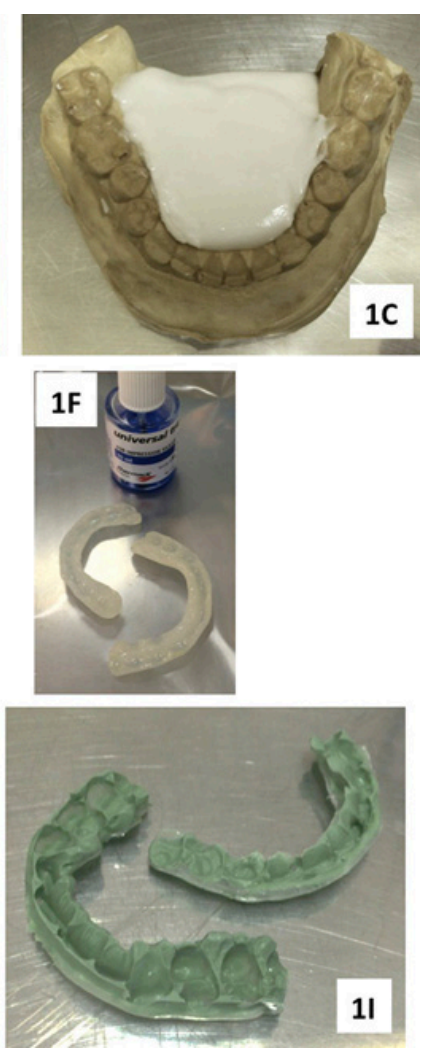

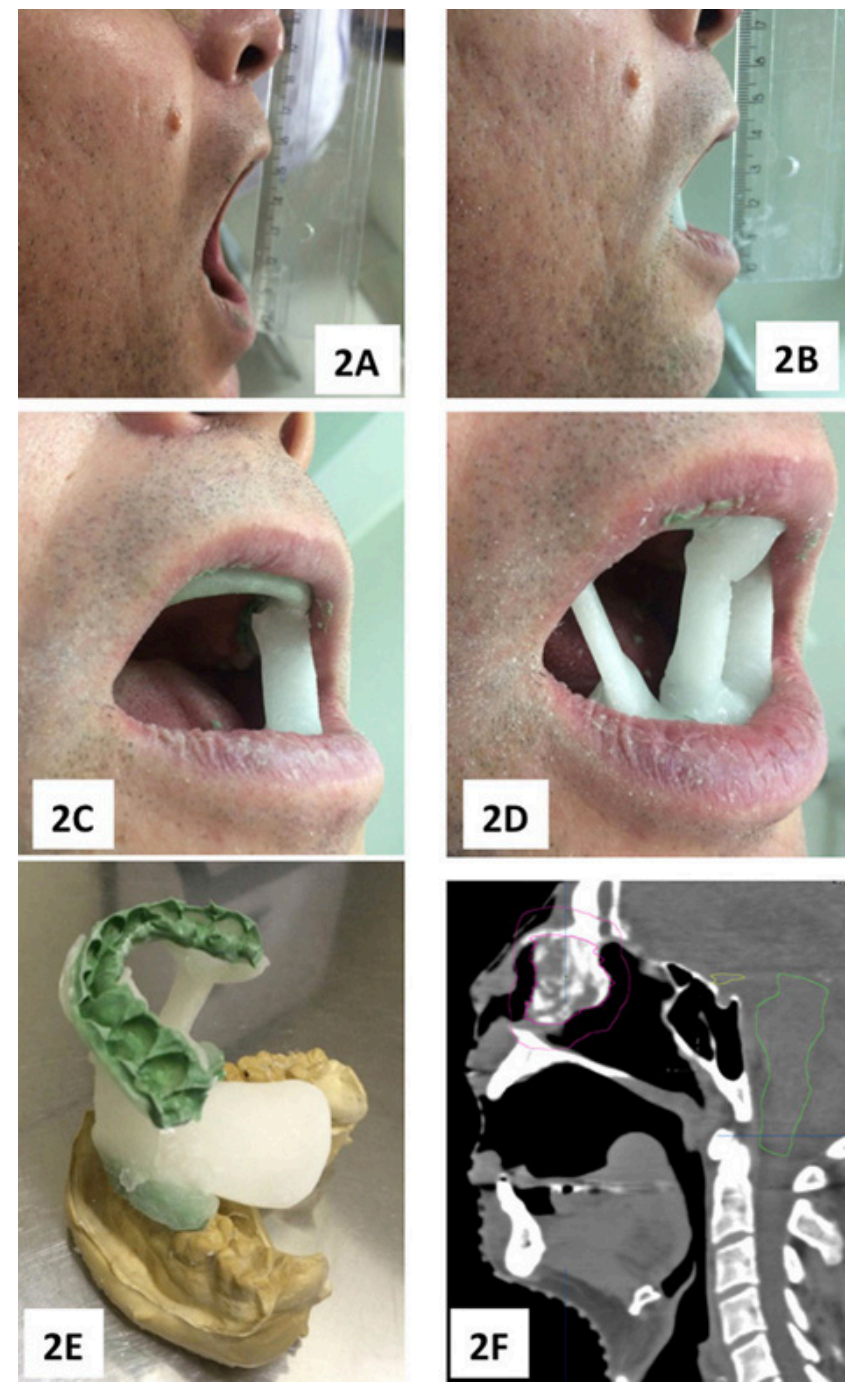

Figure 2. Case \#1

The next step is to assemble the three components in the mouth (upper and lower occlusal stents and lingual plate). In order to proceed, the maximum mouth opening is registered (Figure 2A); after this, the mouth opening in which the three components will be assembled is determined -1.5 to $2.0 \mathrm{~cm}$ less than the maximum mouth opening (Figure 2B). The components are assembled with a mouth opening inferior to the maximum in order to facilitate the device's insertion for the radiotherapy sections, which can cause muscular trismus in some cases.

Acrylic bars are fixated using auto polymerized acrylic directly in the mouth, connecting the upper with the lower occlusal stents in the predetermined mouth opening (Figures 2C and 2D). In the sequence, the lingual plate is fixated in the lower occlusal stent directly in the mouth or in the cast stone (Figure 2E).

After the fabrication of the mouth opener positioner, the patient (and the radiation doctor) is oriented to take the planning tomography using the positioner, use the positioner during the fabrication of the radiation mask, and use the positioner during all sections of radiotherapy. All instructions are spoken and written to the patient and emailed to the radiation doctor.

Figure 2F shows that the radiation prosthesis is effective in locking the tongue into a fixed position (not letting it to be positioned into the palate), and shows that the mandible and, consequently, the submandibular and sublingual salivary glands are kept away from the radiation field, which is concentrated into to the maxilla and nasal floor.

\section{CASE \#2. Patient with carcinoma in the pre maxilla region (Figure $\mathbf{3}$ )}

Figures 3A (upper cast stone) and 3B (lower cast stone) show the intra oral situation of an edentulous patient, with implants placed 2 weeks before (with no possibility for an anchor for the mouth opener device due to the recent healing process). With the impossibility of manufacturing a conventional mouth opener with auto polymerized acrylic, a plastic tray and plastic examination stick were adapted to fabricate a mouth opener positioner (Figure 1C).

Condensation silicone impression material was placed into the tray and filled all of the space from the mandible and the maxilla, where pieces of the plastic stick were placed within the silicone bulk to promote sustainability and rigidity to the final device. Immediately after placing the material in the mouth, the patient was asked to close the mouth a little bit ( 1.5 to $2.0 \mathrm{~cm}$ from the maximum mouth opening), as shown in Figure 3D.

Condensation silicone impression material was chosen to fabricate this patient's devise because it is easy to trim into the final form with a scalpel blade.

To finalize the mouth opener, the tray cable was removed and all unnecessary silicone material was trimmed to promote an easy insertion and removal of the device into the mouth (Figure 3E).

Figure 3F shows that the radiation field was adequately kept away from healthy organs, such as the mandible and submandibular and sublingual salivary glands.

The patient was oriented to use the mouth opener positioner during all radiotherapy fazes: planning tomography acquisition, radiation mask fabrication, and radiotherapy sections.

\section{CASE \#3. Patient with tongue carcinoma (Figure 4)}

This patient had an edentulous mandible; the carcinoma removal from the left side of the tongue left this organ sutured to the left alveolar ridge of the mandible. The only alternative was to take an impression of the right side of the mandible with a partial tray in order to fabricate an acrylic saddle for the right alveolar ridge. Figure 4A shows how the radiation prosthesis was assembled: arrow \#1 shows an upper occlusal stent that was directly glued with auto polymerized acrylic into the acrylic saddle (arrow \#2). This was 1.5 to $2.0 \mathrm{~cm}$ shorter than the maximum mouth opening, and into these two components were glued an acrylic lingual plate to stabilize the tongue (arrow \#3). 
Figure 4B shows the efficiency of the device in keeping the mouth open in one predetermined position as well as stabilizing the tongue's position.

Figure $\mathbf{4 C}$ shows that the radiation prosthesis is able to hold the mouth open and Figure 4D shows that the device is efficient in keeping the radiation field away from the maxilla. Consequently, most of the parotid was also protected from radiation due to the mouth opening.

In same manner, the patient was oriented to use the radiation prosthesis in all phases of the radiotherapy.
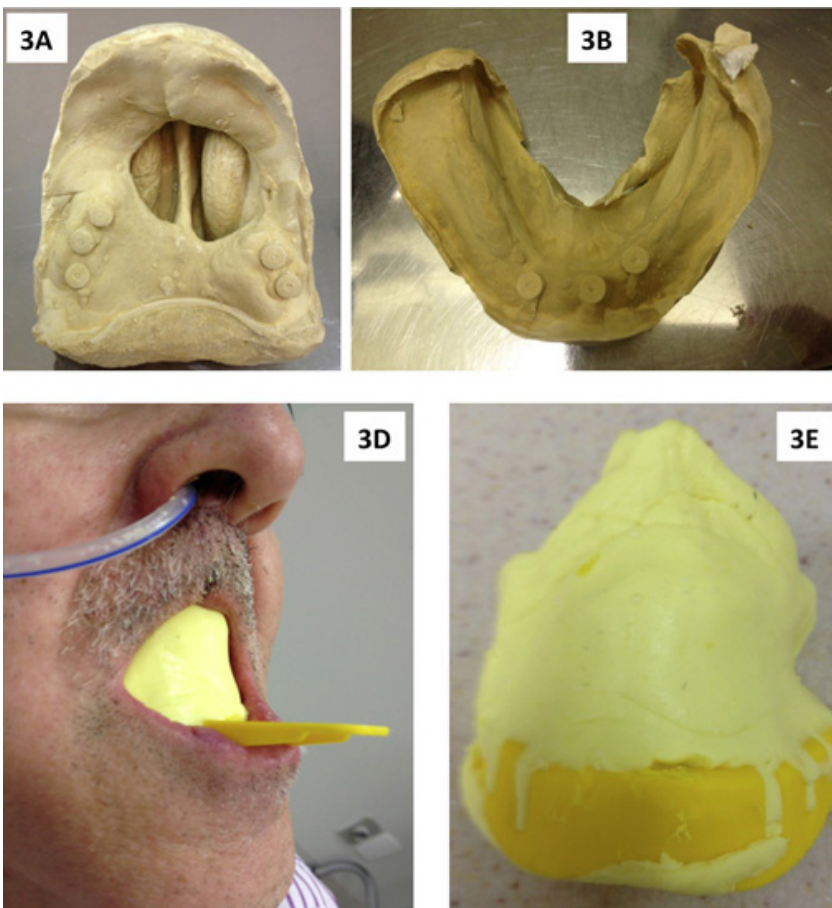

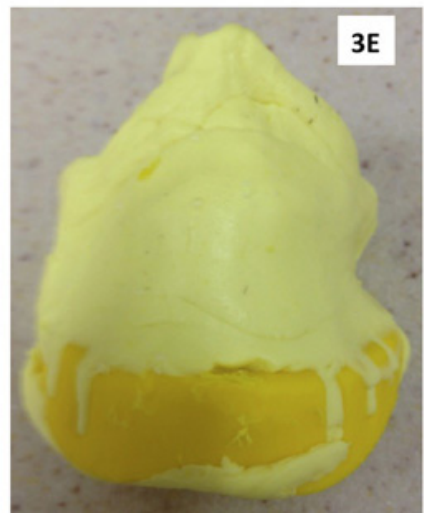

$3 E$

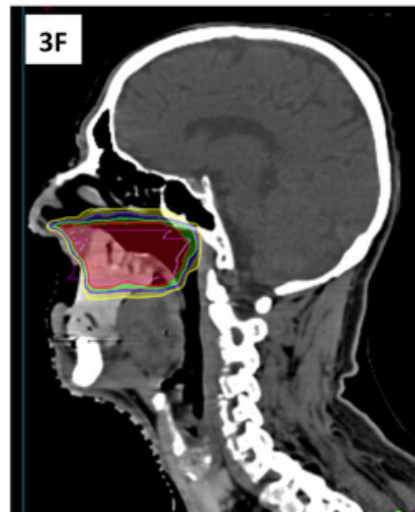

Figure 3. Case \#2

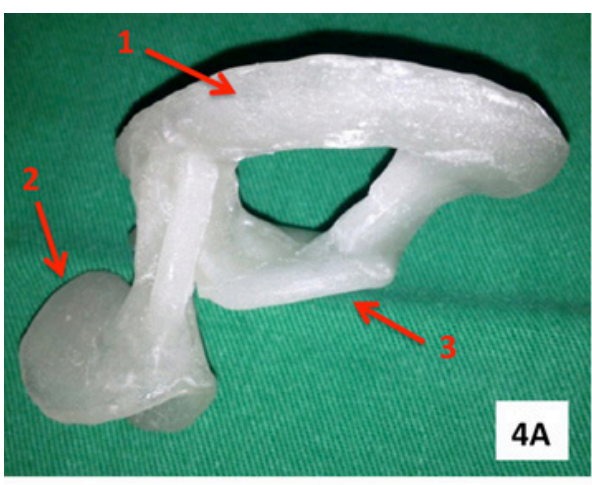

$4 A$
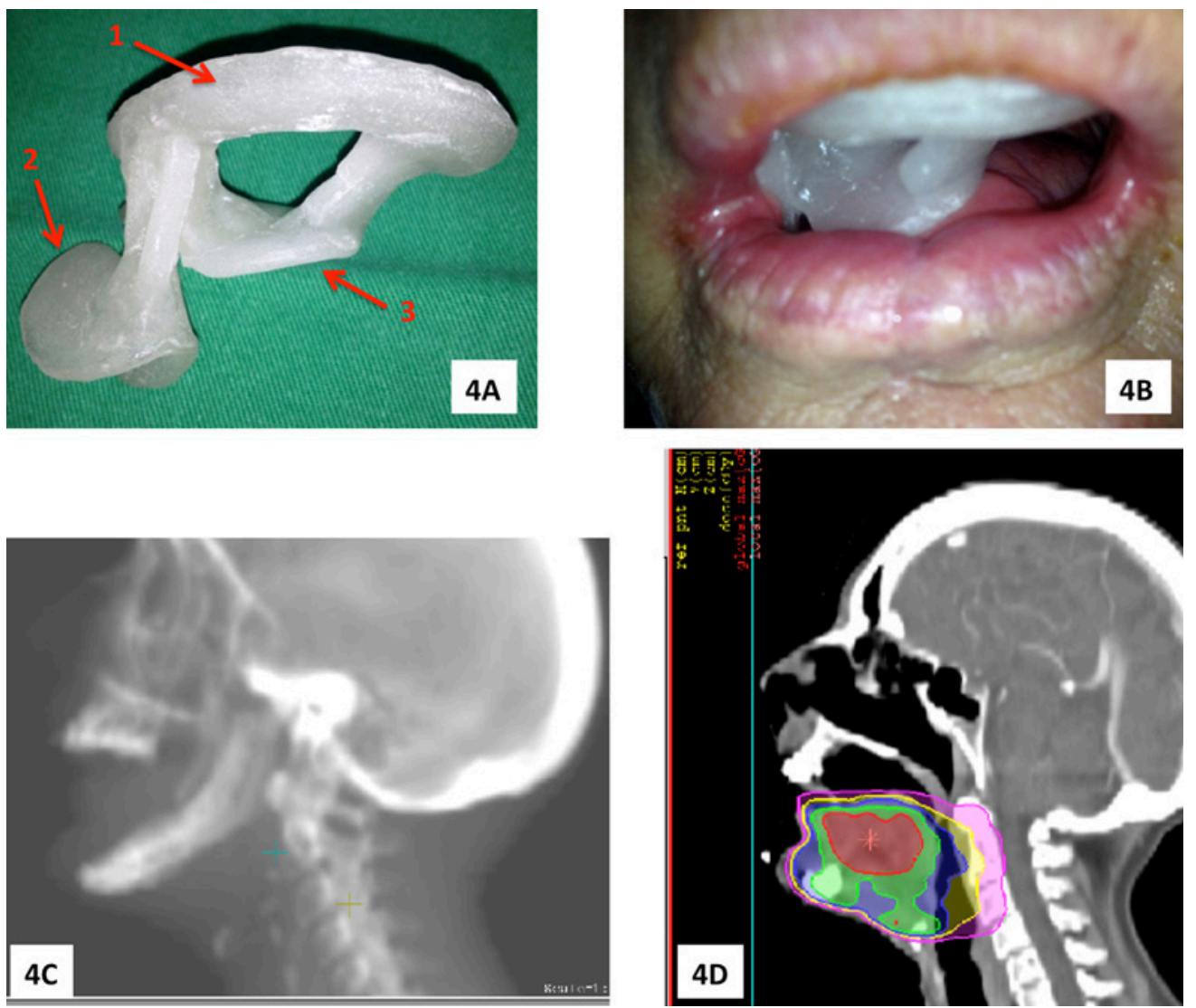
CASE \#4. Patient with bone metastasis in the left side of the mandible (Figure 5)

The objective with this patient was to promote mouth opening and adequate position in order for the radiation treatment not to affect the maxilla, upper teeth, or parotid glands. For this purpose, a bite block was made with auto polymerized acrylic resin (Figure 5A). The bite block was trimmed and adjusted to promote a mouth opening 1.5 to $2.0 \mathrm{~cm}$ shorter than the maximum (Figure 5B). The next step was to register, directly in the mouth, the lower teeth positioning and mouth opening position with Patter ${ }^{\mathrm{TM}}$ resin (Figures 5C and 5D). After registering the lower teeth, Pattern $^{\mathrm{TM}}$ resin was placed in the upper side of the bite block, and the patient was asked to bite to register the final mouth opening and the position of the maxillary teeth (Figure 5E).

Figure 5F shows the customized bite block in position; the red arrow made of Pattern ${ }^{\mathrm{TM}}$ resin in front of the device was made to facilitate the written instruction delivered to the patient and radiation doctor. (A picture of the device can also be sent to the patient and radiation doctor by email or WhatsApp).
Figure 5G shows how the radiation field would be without the mouth opener bite block; the maxilla and all surfaces of the tongue would be hit by radiation. Figure 5H shows the radiation field with the customized bite block in position, where it can be observed that all of the maxilla and at least half of the tongue are kept out of the radiation main field.

\section{CONCLUSIONS}

The cases presented in this paper show that radiation prostheses are efficient in keeping healthy anatomic structures away from the main radiation field, which is in conformity with scientific literature [24,25]. By keeping the mandible away from radiation in cases of tumors of the maxilla or nasal floor, and by keeping the maxilla away from radiation in cases of tumors next to the inferior arch, the healthy structures receive less radiation and, consequently, the risk of osteoradionecrosis is decreased in the arch opposed to the tumor, as well the incidence of oral mucosites [26,27].
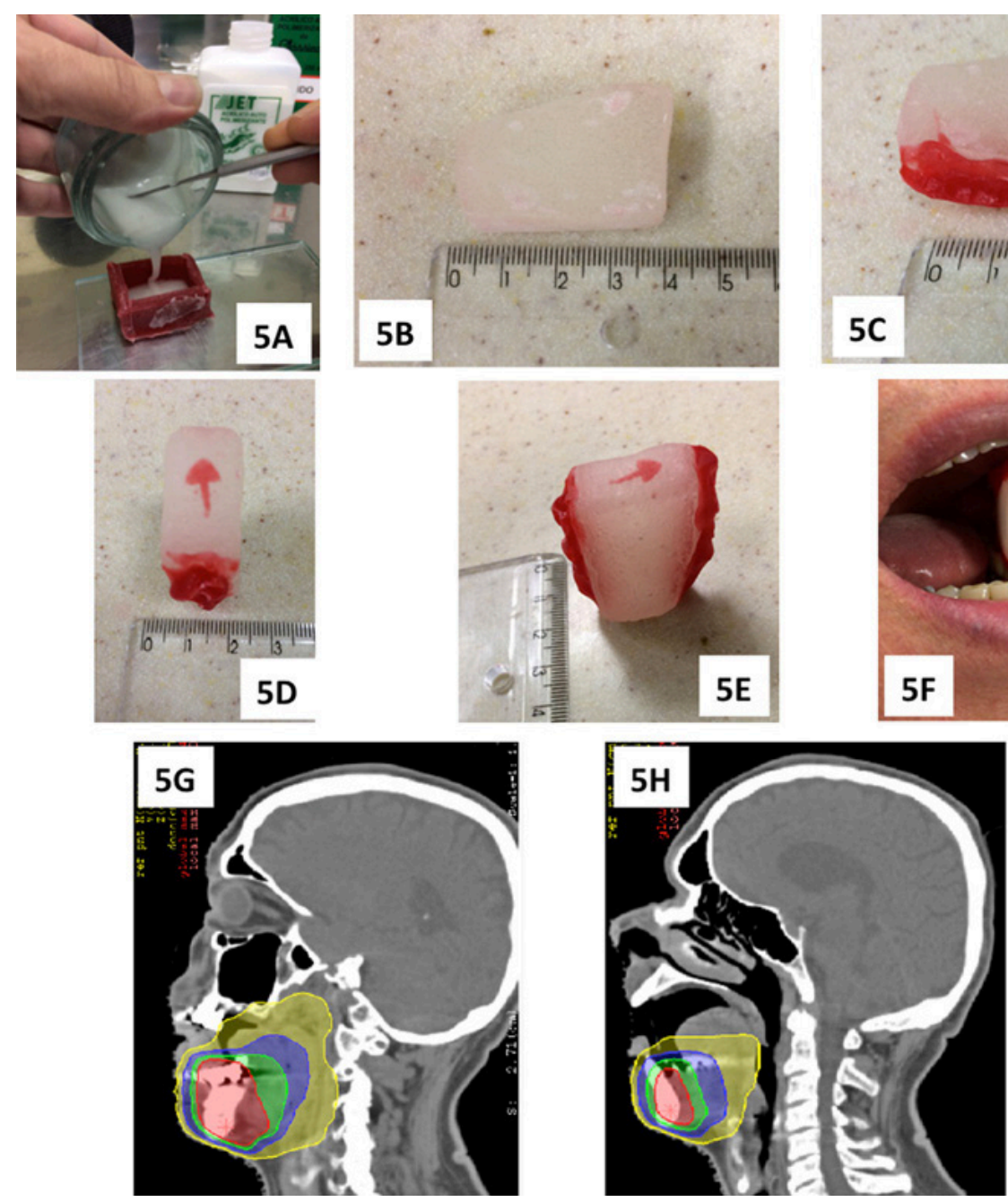

Figure 5. Case \#4
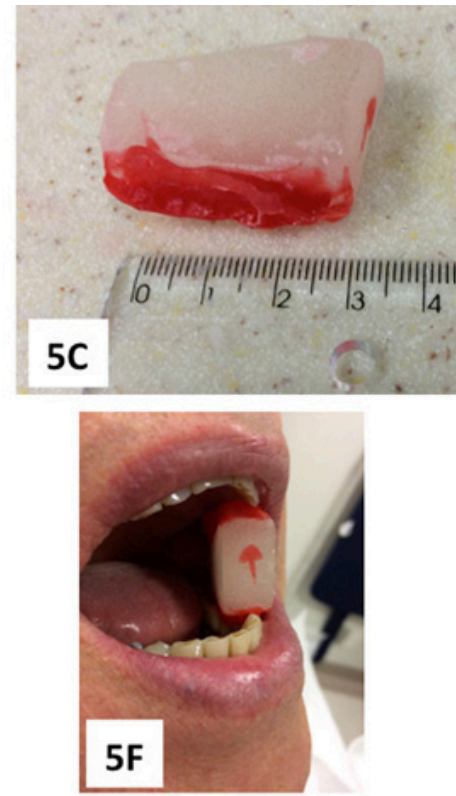
The mouth openers and positioners for radiotherapy, as demonstrated in the presented cases, are efficient in keeping the major salivary glands from the radiation field, preserving submandibular and sublingual salivary glands when the tumor is in the upper dental arch or nasal floor, and preserving most of the parotid salivary glands when the tumor is related to the lower arch (mandible, tongue or mouth floor). Scientific literature has shown that this protection of the salivary glands can decrease and attenuate the xerostomia caused by the radiation treatment of head and neck tumors $[27,28]$. The preservation of salivary flow decreases the risk of dental caries and consequently reduces the risk of osteoradionecrosis.

Therefore, it can be concluded that direct fabrication of intra-oral appliances for radiotherapy are quick and easy to make and extremely cost-effective because they prevent permanent damage in important organs, such as the major salivary glands.

\section{ACKNOWLEDGEMENTS}

The authors would like to thank the Dental and Radiotherapy services of the Moinhos de Vento Hospital (www.hmv.org.br).

\section{REFERENCES}

1. Kielbassa AM, Hinkelbein W, Hellwig E, Meyer-Lückel H. Radiationrelated damage to dentition. Lancet Oncol 2006;7(4):326-35. https://doi. org/10.1016/S1470-2045(06)70658-1

2. Teguh DN, Levendag PC, Ghidey W, van Montfort K, Kwa SL. Risk mode and nomogram for dysphagia and xerostomia prediction in head and neck cancer patients treated by radiotherapy and/or chemotherapy. Dysphagia. 2013;28(3):388-94. https://doi.org/10.1007/s00455-012-9445-6

3. Nabil S, Samman N. Incidence and prevention of osteoradionecrosis after dental extraction in irradiated patients: a systematic review. Int $\mathrm{J}$ Oral Maxillofac Surg 2010;40(3):229-43.

4. Beetz I, Schilstra C, Burlage FR, Koken PW, Doornaert P, Bijl HP, et al. Development of NTCP models for head and neck cancer patients treated with three-dimensional conformal radiotherapy for xerostomia and sticky saliva: the role of dosimetric and clinical factors. Radiother Oncol. 2012; 105(1):86-93. https://doi.org/10.1016/j.radonc.2011.05.010

5. Dobroś K, Hajto-Bryk J, Wróblewska M, Zarzecka J. Radiation-induced caries as the late effect of radiation therapy in the head and neck region. Contemp Oncol (Pozn) 2016;20(4):287-90. https://doi.org/10.5114/ wo.2015.54081

6. Owosho AA, Tsai CJ, Lee RS, Freymiller H, Kadempour A, Varthis S, et al. The prevalence and risk factors associated with osteoradionecrosis of the jaw in oral and oropharyngeal cancer patients treated with intensitymodulated radiation therapy (IMRT): The Memorial Sloan Kettering Cancer Center experience. Oral Oncol 2017;64:44-51. https://doi.org/10.1016/j. oraloncology.2016.11.015

7. Lee IJ, Koom WS, Lee CG, Kim YB, Yoo SW, Keum KC, Kim GE, Choi $\mathrm{EC}, \mathrm{Cha} \mathrm{IH}$. Risk factors and dose-effect relationship for mandibular osteoradionecrosis in oral and oropharyngeal cancer patients. Int $\mathrm{J}$ Radiat Oncol Biol Phys. 2009;75(4):1084-91. https://doi.org/10.1016/i. ijrobp.2008.12.052

8. Morais-Faria K, Menegussi G, Marta G, Fernandes PM, Dias RB, Ribeiro $\mathrm{AC}$, et al. Dosimetric distribution to the teeth of patients with head and neck cancer who underwent radiotherapy. Oral Surg Oral Med Oral Pathol Oral Radiol. 2015;120(3):416-9. https://doi.org/10.1016/j.0ooo.2015.05.009

9. Nabil S, Samman N. Risk factors for osteoradionecrosis after head and neck radiation: a systematic review. Oral Surg Oral Med Oral Pathol Oral Radiol. 2012;113(1):54-69. https://doi.org/10.1016/j.tripleo.2011. 07.042

10. Ahmed M, Hansen VN, Harrington KJ, Nutting CM. Reducing the risk of xerostomia and mandibular osteoradionecrosis: the potential benefits of intensity modulated radiotherapy in advanced oral cavity carcinoma. Med Dosim. 2009;34(3):217-24. https://doi.org/10.1016/j.meddos.2008 08.008
11. Ward MC, Ross RB, Koyfman SA, Lorenz R, Lamarre ED, Scharpf J, et al Modern Image-Guided Intensity-Modulated Radiotherapy for Oropharynx Cancer and Severe Late Toxic Effects: Implications for Clinical Trial Design. JAMA Otolaryngol Head Neck Surg 2016;142(12):1164-70. https://doi. org/10.1001/jamaoto.2016.1876

12. Nguyen NP, Kratz S, Lemanski C, Vock J, Vinh-Hung V, Olena G et al. Image-guided radiotherapy for locally advanced head and neck cancer Front Oncol. 2013 July 8;3:172. https://doi.org/10.3389/fonc.2013.00172

13. Jiang $N$, Zhao $Y$, Jansson $H$, Chen $X$, Mårtensson J. Experiences of xerostomia after radiotherapy in patients with head and neck cancer: a qualitative study. J Clin Nurs. 2017;17

14. Gerdin EW, Einarson S, Jonsson M, Aronsson K, Johansson I. Impact of dry mouth conditions on oral health-related quality of life in older people. Gerodontology 2005;22(4):219-26. https://doi.org/10.1111/j.17412358.2005.00087.x

15. Kojima $Y$, Yanamoto S, Umeda M, Kawashita $Y$, Saito I, Hasegawa T, et al. Relationship between dental status and development of osteoradionecrosis of the jaw: a multicenter retrospective study. Oral Surg Oral Med Oral Pathol Oral Radiol 2017. https://doi.org/10.1016/j. 0000.2017 .04 .012

16. Vissink A, van Luijk P, Langendijk JA, Coppes RP. Current ideas to reduce or salvage radiation damage to salivary glands. Oral Dis. 2015:21(1) e1-10. https://doi.org/10.1111/odi.12222

17. Gulbransen H \& Beumer III J - Use of Splints and Stents during Radiation Therapy - Foundatition for Oral-facial Rehabilitation, Acesso em: 21 set. 2017, Disponível em: http://www.ffofr.org/education/lectures/maxillofacialprosthetics/use-of-splints-stents-during-radiation-therapy/

18. Ranabhatt Jr II R - Radiation therapy and its Prosthodontic implications - Foundatition for Oral-facial Rehabilitation, Acesso em: 21 set. 2017. Disponível em: https://www.slideshare.net/ranikgdu08/radiation-therapyand-its-prosthodontic-implications

19. Jaguar GC, Lima EN, Kowalski LP, Pellizzon AC, Carvalho AL, Boccaletti $\mathrm{KW}$, Alves FA. Double blind randomized prospective trial of bethanecho in the prevention of radiation-induced salivary gland dysfunction in head and neck cancer patients. Radiother Oncol. 2015;115(2):253-6. https:// doi.org/10.1016/j.radonc.2015.03.017

20. Cotomacio C, Campos L, Simões A, Jaguar G, Crosato EM, Abreu-Alves $\mathrm{F}$. Influence of bethanechol on salivary parameters in irradiated patients. Med Oral Patol Oral Cir Bucal 2017;22(1):e76-83.

21. Yang WF, Liao GQ, Hakim SG, Ouyang DQ, Ringash J, Su YX. Is Pilocarpine Effective in Preventing Radiation-Induced Xerostomia? A Systematic Review and Meta-analysis. Int J Radiat Oncol Biol Phys 2016;94(3): 503-11. https://doi.org/10.1016/j.ijrobp.2015.11.012

22. Simões A, de Campos L, de Souza DN, de Matos JA, Freitas PM, Nicolau $J$. Laser phototherapy as topical prophylaxis against radiation-induced xerostomia. Photomed Laser Surg. 2010;28(3):357-63. https://doi. org/10.1089/pho.2009.2486

23. Rieger JM, Jha N, Lam Tang JA, Harris J, Seikaly H. Functional outcomes related to the prevention of radiation-induced xerostomia: oral pilocarpine versus submandibular salivary gland transfer. Head Neck 2012;34(2) 168-74. https://doi.org/10.1002/hed.21682

24. Verrone JR, Alves Fde A, Prado JD, Boccaletti KW, Sereno MP, Silva ML, Jaguar GC. Impact of intraoral stent on the side effects of radiotherapy for oral cancer. Head Neck. 2013;35(7):E213-7. https://doi.org/10.1002/ hed.23028

25. Johnson B, Sales L, Winston A, Liao J, Laramore G, Parvathaneni U. Fabrication of customized tongue-displacing stents: considerations for use in patients receiving head and neck radiotherapy. J Am Dent Assoc. 2013:144(6):594-600. https://doi.org/10.14219/jada archive. 2013.0170

26. Goel A, Tripathi A, Chand P, Singh SV, Pant MC, Nagar A. Use of positioning stents in lingual carcinoma patients subjected to radiotherapy. Int J Prosthodont 2010;23(5):450-2.

27. Verrone JR, Alves FA, Prado JD, Marcicano Ad, de Assis Pellizzon AC Damascena AS, Jaguar GC. Benefits of an intraoral stent in decreasing the irradiation dose to oral healthy tissue: dosimetric and clinical features. Oral Surg Oral Med Oral Pathol Oral Radiol. 2014;118(5): 573-8. https:// doi.org/10.1016/j.0000.2014.08.008

28. Mall P, Chand P, Singh BP, Rao J, Siddarth R, Srivastava K. Effectiveness of Positioning Stents in Radiation-Induced Xerostomia in Patients with Tongue Carcinoma: A Randomized Controlled Trial. Int J Prosthodont 2016;29(5):455-60. https://doi.org/10.11607/ijp.4499 